\title{
ON SOME NEW LEPIDOPTERA DISCOVERED BY A. S. MEEK IN BRITISH NEW GUINEA.
}

\author{
By the Hon. WALTER ROTHSCHILD aNd KARL JORDAN.
}

WT HEN describing in Nov. Zool. xi. p. 310 (1904) some remarkable Lepidoptera obtained by A. S. Meek at Owgarra, situated at a high altitude north of the head of the Aroa River, we mentioned that the outbreak of measles had compelled the collector to return at once to the coast with his men. The few hundred specimens found during two or three days' collecting, among which were the wonderful new Troides chimaera and a number of new Delias, new Lycaenidae, Milionia, etc., were just enongh to show what a fine collection might have been got together if no such deplorable disaster had overtaken the expedition. After all the hardships undergone and the personal danger attendant upon an expedition into the interior, it would have been very natural if the hard luck experienced had discouraged A. S. Meek entirely from going again into the mountains. But our friend's spirit is not easily damped, and the fine things he had found up there did not leave him any peace. We were agreeably surprised to hear from him that he had made preparations to revisit those high regions in order to make a thorongh collection of Lepidoptera, and especially to discover the male of Troides chimaera.

Well, the collection is safely in our hands, and a remarkable one it is indeed. We do not easily get into ecstasies over some new species arriving at Tring, but this collection gave us reason for being astonished. Not only is the percentage of new species very high, but what is more noteworthy, there is a remarkably large number of new genera of which no representatives have been found at lower altitudes. The total number of species is less high than in the first collection made by A. S. Meek on the Upper Aroa River in 1903; but that is only natural, considering the altitude and attendant physical features of the region where the present collection was made. Meek's letters referring to this expedition are very interesting reading. As they give one a good idea of the district collected in, and of the donbtful pleasures a collector must expect to meet if he ventures into the interior of New Guinea, we give here some extracts, which we hope the reader will find as interesting and instructive as we did ourselves. We congratulate Mr. Meek heartily on having achieved such great success in a district where climate and natives are equally bad.

In a letter dated Cooktown, July 4th, 1904, Mr. A. S. Meek told us that he was still undecided about a new expedition to the mountains. "But I am almost sure," he added, "to take that trip. If I do go I intend stopping inland a long time (not for good, I hope), and shall try to get all my boys signed on for twelve months. I shall probably take an extra assistant and a big crowd of collectors, so as to do the thing thoroughly."

A fortnight later he informed us that he was going to leave Cooktown for New Guinea, in order to engage "boys" as collectors and carriers, before proceeding west (from Port Moresby). "The leeches are terribly bad at those 
altitndes. I shall make canvas 'sea-boots' for the boys this time before we start. I am going to try very hard for the male of that hairy Troides, and am taking up a quantity of trade goods and gear to induce the natives to help. I am rather off colour at present through loss of blood. The doctor was in this morning, and managed to stop the bleeding somewhat. I must have lost a quart of blood during the night. If I don't get better I shall not leave for New Guinea by this boat."

Fortunately Mr. Meek recovered sufficiently to leave Queensland. His next letter came from Sariba Island, Samarai, British New Guinea, dated August 10th. "I have not started for the mountains as yet. I was away last week looking for boys, but without success. I have been very unwell lately; in fact, I don't think I shall be fit for much more knocking about without a good long change of climate, which I hope will set me up again. During the first day I was away by myself looking for boys I was sick all the time. I wish it were possible for me to send some one in my place on this next mountain trip ! I should like to get well up in altitude before the birds commence monlting. As I had a good deal of new gear made while I was in Queensland last month, we shall be better equipped and start under better conditions than previously, knowing the language a bit and the natives, besides having my previons experience, which is all worth a great deal. I am also taking a new assistant, though I have as yet my doubts whether he will be of much good to me."

On October 17th Mr. Meek writes from the Aroa River: "I am now fairly on my way to the high mountains, coming this time $v \mathrm{i} \hat{\imath}$ Yule Island. It has taken us one long day by canoe up the inlet, two days by drays (per sandalwood getter), and four days by boat. Of course it is the delay everywhere in getting carriers which eats up the time. Since I started recruiting collectors for this trip just two months and a half have elapsed, and I do not expect to be in camp at the high altitudes before three weeks at the earliest. Please send me some more boxes for insects. I shall most likely come up again, as there is no great point in losing so much time for one collection only-though I want very badly to come home next year. It is strange how one's blood gets so bad out here. A week ago I foolishly struck a native with my hand (instead of taking a lump of wood), and accidentally struck his teeth. Now I have a beautiful hand that may take months to heal. Some years ago you sent me a sketch of a beautiful Delias which has a large orange patch on the underside of the hindwing, with a black dot in it, and of which I got only one specimen last time.* The reason for that, I find, was that we were too high. I have noticed several specimens lower down than this place. We are yet two days below my camp of the first trip. It will take us as long as that on account of the difficulty of procuring carriers. Of course the higher we get the quicker we shall travel, as the population is more numerous and the natives are more willing to carry, owing to their want of trade goods. I shall try to stay four months this time, health permitting. But it is very wet up there, and cold and miserable. It can't be too healthy to have the blankets soaking wet every night, and almost to have to wring them ont every morning! The birds are all starting to moult, I find, so I doubt if I shall do much in that way this time. Besides, I haven't any of my regular South Sea shooting boys with me, whom I have had for so many years. I find my previous knowledge of the language of the very greatest help. I am taking two natives 
from here as interpreters to Owgarra on the mountains. That speaks for itself. They would not have confidence to come if they did not understand one."

On October 21st Mr. Meek reached a place suitable for his camp. To get there from the coast had taken him just a month! The difficulties of travel in those parts are enormous. "My men and carriers got here two days later. I shall try to stop until New Year in this camp. The cold is intense at night. One of my boys had fainting-fits to-day. I put it down to change of climate. He belongs to Kapahapa, a coast village, built over the sea, close to Port Moresby, and is a big, strong fellow. This place is only six or seven hours from my old camp of the second trip, but is very much higher, as one has two big mountains to climb, and comes down very little. I came over accompanied by six boys, and was in clouds from the time of leaving camp; it was raining all the way. When I got here I mentally resolved to go back the next day; bat at daybreak the next morning everything looked so bright and promising that I sent carriers back to bring our gear.

"The man I mentioned yesterday as being ill had to be strapped up all night for fear of his doing some damage. He went off his head again in the early part of the night, and cleared into the bush with a couple of long net-handles, under the impression they were spears. I had to send the boys out with a lamp to find him. They found him collapsed, but he was violent enough when bronght into camp. I have another man who went off his head, but was quite harmless (so far). He has had only one attack. He told me the next morning, 'S'pose my place, boy make'm hand leg fast, longa maina (rope), bye'mbye t'morrow all right finish.' I have sent my mail-boys down to the coast, and hope they will bring the insect-boxes, which have arrived there.

"A white man, a prospector, accompanied me to the Aroa River, where I had to leave him. He seemed too scared of the natives to bring him along to places where there is a chance of the natives being bad. The people up here killed a man about four days ago belonging to a village situated on the next spur to this one. Next day they could distinctly be heard from here wailing. The people here have repeatedly asked me to go and shoot the neighbonring crowd! One can count over thirty villages from here. It is too cold at this altitude. The boys can't stand it; they are shivering all night, and complain most bitterly of the cold. It's no wonder, for I myself find it difficult to keep the cold ont at night with two woollen singlets and cloth jacket, besides being under a heavy rug. When it is raining or clondy (fog) it is not too bad; but these clear nights the cold is very piercing. From my camp here, on a clear morning, we can see over the head of this river and on to the watershed of the Tanapa, which river can be traced to its head, a distance from here I should estimate to be about twenty miles in a direct line. Please don't imagine I am telling you this in the expectation or hope of your wanting me to go there, for I should be very reluctant to go. To get to the head of the Tanapa from here would take, I should say, about three weeks (!), not allowing for hostile natives. We are camped on a spur high up on the side of a valley, and on a sunshiny morning it makes a very pretty sight looking down the valley; it's all grass, extending low down, being divided into paddocks with villages, resembling farms and meadows of some places in England. There is another big tribe named Endever higher up on this river ; I can just make out the first of their villages from here. I may send collectors there if any people come down from there 
visiting my camp, though I am doubtful if there would be much difference in the insects. The villages are much closer to the river than we are, which accounts for ns being able to see over the head of the watershed.

"It will be a wonder to me if I get through these next two months without some sort of friction with the natives. These people here are quite different from the Aroa River lot, being lazy, and inclined to be saucy when there is a big crowd of them. When in Cooktown last I bought two kangaroo dogs (stag hounds). The dog got bitten by a snake on the road up, and died. The bitch gave birth to six pups four days ago, since when she has developed man-eating propensities. I have had to pay several natives for her tackling them, and have now no difficulty whatever in keeping the camp clear of natives. They are only used to such little rats of dogs that the size alone of this one scares them.

"I find the man I brought up from the Aroa River is of very little good, in fact nseless, as interpreter, and I never use him for that purpose, as I am able to make the natives here understand myself. They know much more of the Aroa River language than I thought. This chap's mate left me on the road: he got scared at seeing so many natives. I am rather sorry that the other man did not bolt too.

"This place certainly 'takes the bun' for rain. So far it has been raining every afternoon. Last time I was at Cooktown I sent to Brisbane for seven air-tight boxes and an acetylene-gas lamp, and am now very thankful I did. I have a staging rigged over the edge of the steep slope, almost a precipice, and put the lamp on that and work the nets. I am rather disappointed as regards day-flying moths: I expected to find many more. I have one medium-sized white Nymphalid with simple tail like Charaxes. The insect has black underside with white stripes.* Then I have the almost pure white Morphotenaris nivescens, and a grey and white Tenaris with narrow forewing, which I have not met with before. There are perhaps altogether eight or nine fair-sized butterflies which are new to me, but any amount of new moths. These are rather the rule than the exception this time, especially among the Geometridae. I have so far taken all the Pieridae found before on the Aroa River and at Owgarra, with the exception of one, and have a fair number of moths. The latter I find resemble very much European things, more particularly the moths which sit on bark or wood."

Soon after arrival at his destination Mr. A. S. Meek saw two males of Troides. "While waiting for the carriers I went down to the bed of the river to look at the conntry for collecting purposes and to select a suitable place for the camp. I had just started to come up, when a native sang ont, and not more than fifteen yards away I saw a male Troides going down fair wind at a great rate. I most distinctly saw it was green, and at the time felt very disappointed, as I took it for the common form. The second male, which I saw some days later, was a big black and golden specimen that went past the camp. Several people saw it, and one man had a shot at it with small shot. It seemed to be hit, as it spun round, then closed its wings and disappeared over a precipice. I had all the boys out then, what time it was not raining, looking for it, but without success.

"The natives have brought me in four damaged females of the common kind, but more velvety black."

"Since writing last," Mr. Meek proceeds in his letter of November 14th, "the natives have brought in four males of the common green Troides, thus 
clearing up any doubts about the females previously mentioned; and also one female of the banded Troides." I obtained an egg from her, but am doubtful of finding the creeper here to rear the larva on. I have also seen one more male, black and gold, presumably of the species with the banded body. Now is the first quarter of the moon. I shall stop here until the first full moon after next-that is, about five weeks."

On November 16th Meek obtained the male of Troides chimaera. "I have the male at last! It is a most beantiful insect, all black and gold. There are three long stripes on the forewing; the hindwing is semitransparent and gold, inclining to be tailed.

"I am not bothering much about birds, the leeches being too bad. I told you before, I have no good shooting-boys this trip, consequently my assistants have an easy time. Birds are not worth collecting unless one can utilise the shootingboys as boat's crew.

"I got a small Charaxes-like butterfly new to me. It is greenish white with deep black border. $\dagger$

"We have had a spell of comparatively dry weather," A. S. Meek continues on November 22nd, "and have made several additions to the collection. There is one large 'Owl-butterfly,' chocolate, with large eyes on the hindwing; it has a similar eye near the tip of the forewing and a large cream or yellow band. $\neq$ I have also two more females of the banded Troides chimaera, and a female of a possibly new species (though doubtful), with the forewings black and the hindwings dark yellow and black. $\$$ There is yet another Pierid, for which I think you will have to make a new genus, and several handsome day-flying moths. The collection is going to become a good one. The Troides male alone is worth coming for, if one could only afford to collect for pleasure. It is the most handsome and the largest species I have seen. The specimen is absolutely perfect. I have now two fertile eggs of the species."

Mr. Meek did not succeed in rearing the larvae.

As the consignment of insect-boxes despatched from Tring had not reached him before starting for the monntains, Meek was rather short of boxes for the set insects. On December 6th he writes: "I have been busy all day shifting specimens, repacking and throwing away any damaged specimens of insects, trying to economise space so as to be able to make a longer stay than originally intended. So you can judge what my joy was to see my mail-boys coming back, after fourteen days' absence, with two packs of store-boxes and a big mail. I will now stay longer here, in spite of the tronblesome natives. By Jove! after getting my camp safely away, I should like to come back and punish a few of these niggers here most severely. There are some here with whom I should not put up any longer, if it was not for getting the camp away. They are too trying. I do not know which way to go back, as I am afraid of the Aroa River in the wet season, on account of getting the collections over. Perhaps I shall go back the way I came up the first time.

"Four of my boys have run away.

"I have got another female of the banded Troides, perfect, with the exception of the legs being lost. The natives shot all the females with pronged arrows. I felt more pleased when the male of this species was brought in than if $I$ had been

\footnotetext{
* Troides chimaera.

$\dagger$ Heleyra.
}

‡ A new Morphopsis.

$\S$ Aberrant $q$ of exphorion. 
left a fortune. I gave the boy two shillings, two tins of English bacon, and five sticks of tobacco. I have got what I came for, so I am satisfied. Of the Morphotenaris I have a fair series now, but we are too high for the tailed Troides." *

It was not a particularly fine Christmas that our friend spent up there in his mountain camp, near the head-waters of the Angabunga River, a southern affluent of the St. Joseph River. " Rain all day yesterday and to-day," he writes on December 25th. "My mail-boys have been away eighteen days, and are not back yet. Up to the present I have set abont 5600 insects, and have everything now that I came for, and am in hopes of getting more of that fine Troides. I have lately been getting local natives to work for them, but cannot get any good specimens besides the first one.

"Three days ago I had to go across to another village to make friends (or otherwise) with the natives of Sotamah, on account of the people here at camp telling me they were afraid of going there to collect, as the Sotamah people were threatening them with spears from above on the hillside. I have been expecting a pig and native food yesterday or to-day, as a sign of good-will resulting from my journey, but the rain has apparently delayed them.

"You will probably recollect my mentioning some time ago that I thought you had made a mistake in stating I only got one female of Papilio weiskei during my stay at the Aroa River in 1903. Well, I have kept this time all the specimens, both good and bad, and find that I have several females, but not one like the single green female specimen figured by you.

"If I could only find the proper food-plant of the banded Troides, I could breed a lot. I have fully fifteen eggs of the species; some have already hatched, but the larvae have died. The natives shoot the females, as I said before, with bows and arrows.

"I have read Mr. Pratt's article describing his expedition to the Aroa River (Dinawa and neighbourhood). It is rather amusing reading for one who knows the country. 'So thick was the forest that scarcely any light penetrated' . . . ' and as it was raining most of the way, not a sound was heard or a sign of life, etc.' I suppose this is the approved style of writing about a tropical country. But you will perhaps be interested to hear that down near the coast 'game' abounds. It is usual for a person who has any go in him to be ahead of the carriers with rifle or gun to shoot game. The last time I came up (last year, on the 'measle' trip), we got three Goura pigeons, one cassowary, one 'turkey,' two wallabies, and, with dynamite, about a hundredweight of fish in one day's travelling. I only wish we had some of the game up here.

" The hindwing of the banded Troides, when alive or fresh, is almost a transparent gold. I saw a specimen some hundred feet high up some days ago, and the hindwings were so conspicuous that the specimen looked as if it had brilliant yellow tails. I notice that the transparency disappears more or less when the specimen is dead and dried. I notice too that in the old specimeus the greenish golden colour along the costal margin of the forewing has turned to blnish green on account of sun or weather.

"I am going to send this letter down by native carrier to-morrow (December 29th). I have heard to-day from the natives that some of the boys I sent down on the 8th have been killed by the Powra people, and that the remainder are afraid of coming back here. So if this letter reaches you, it is lucky. I am sending it by a different route, along the south side of the Aroa instead of the north, which was the 
way we came after leaving Booboonie on the Aroa. I shall probably go that way myself on the return, as I don't want to jeopardise this collection by hostile natives. I shall not stop more than six weeks here. I have enough of it. This incessant rain is very disheartening. It's not too bad when one has plenty of work, but that is impossible when it is raining so much. There is no doubt a collector earns all he makes. This killing business will make the remainder of my boys very chary of going far from camp.

"Jannary 7th.-I have been unable to get a native to bring this letter down. As I got further news that all my boys whom I had sent down to the coast, as well as the runaways, had been killed, I had the camp packed up ready to start. To my surprise, shortly before sundown the boys reported to be killed turned up, bringing my mail and a little flour and sugar.

"I have got another new 'Owl-Butterfly" and several male specimens of the rare Troides. I am too high for goliath and meridionalis, except in the bottom of the valley below us, where one can get most of the coast things. But I do not work there on the meagre chance of getting these rarities.

"I shall leave here in February via the Aroa. We have to cross the Aroa in two places ; it means a big swim, the river being very rapid in flood."

The collection has arrived at Tring in very good order. Besides the male of Troides chimaera, the two fine new Morphopsis, the splendid Lycaenids and dayflying moths, the most noteworthy Lepidoptera obtained are some new genera of Satyrinae allied to Hypocysta and a new genus of Saturniidae allied to the IndoJapanese genus Rhodia. One of these Satyrinae is a mimic of Mynes websteri and some Pierids. The peculiar Phirdana weiskei Rothsch. (1901) is apparently not rare at that high altitude ; also Acraea meyeri Kirsch (1877) was met with in some numbers. The Delias discovered by Weiske and Meek on the Aroa are all represented in the collection, mostly in fine series, there being also one conspicuous new Delias, and another new Pierid for which we have to propose a new genus. There are only a few species of Euploea and Tenaris, $\dagger$ while the Lycaenids are well represented. We describe only some of the novelties in the present paper, as lack of time prevents us from studying all the species collected.

The specimens are all from the Angabunga River, a southern affluent of the St. Joseph River, $6000 \mathrm{ft}$. and upwards, November 1904 to February 1905.

\section{NYMPHALIDAE.}

Sexes similar.

\section{Morphopsis ula spec. nov.}

§. Body mummy-brown above, greyish tawny-olive beneath; palpus with two pale lateral lines, one beneath and the other above.

Wings, upperside, pale chestnut._-Forewing: distal margin scalloped, hinder margin strongly rounded-dilated; a broad band from two-thirds of costal margin to distal margin, reaching the latter between $\mathrm{M}^{1}$ and $\left(\mathrm{SM}^{1}\right)$, creamy, washed with ochraceous behind, proximally incised or sinuate on or just behind the veins, the disc brown between apex of cell and creamy band; a band of four large black spots from $\mathrm{SC}^{4}$ to $\mathrm{R}^{2}$, not separated, the first spot indistinct, the second and third elongate, the fourth round, the last three centred with bluish white; three brown

* A second new Morphopsis.

$\dagger$ On the lower Aroa River Mr. Meek found a series of Tenaris butleri Oberth. (1879). 
submarginal halfmoons $\mathrm{R}^{2}-\mathrm{M}^{1}$, followed distally by a brown admarginal line which is broken at the veins ; marginal area olive-black from $\mathrm{R}^{2}$ costad, ochraceous tawny backward; fringe olive._- Hindwing scalloped; costal area, inclusive of almost the entire discoidal cell, and abdominal area from $\left(\mathrm{SM}^{1}\right)$ backwards olivebistre, distal edge washed with olive; a very large black ocellus $\mathrm{M}^{1}-\mathrm{M}^{2}$, centred with white and blue and encircled by an ochraceous tawny ring, the ocellus extending beyond veins $M^{1}$ and $M^{2}$, occasionally a small ocellus between $R^{3}$ and $M^{1}$ and another between $\mathrm{R}^{2}$ and $\mathrm{R}^{3}$; a reversedly crenate pale tawny submarginal line bordered with blackish brown on both sides.

Underside olivaceous wood-brown, somewhat clayish._-Forewing washed with olive-black from $\mathrm{M}^{2}$ forward; an olive-black band across middle of cell, bordered on both sides by olivaceous wood-brown, the distal one of these pale border-lines angulate and contignons with an olive-black line which gradually shades off distally; a curved row of olivaceons wood-brown halfmoons from $\mathrm{M}^{2}$ costad, strongly arched, open distally ; a short creamy-white costal band costally of these halfmoons, the band reappearing between $R^{2}$ and $R^{3}$, the olive-black space between the white markings (and further back) being sharply limited by a pale line ; ontside the white spot $\mathrm{SC}^{5}-\mathrm{R}^{1}$ a chocolate patch; an irregular row of ocelli from $\mathrm{SC}^{2}$ to $\mathrm{M}^{2}$, ocelli $\mathrm{R}^{1}-\mathrm{R}^{2}$ and $\mathrm{M}^{1}-\mathrm{M}^{2}$ black, ringed with wood-brown and olive and centred with white; the other ocelli more or less wood-brown, ringed with olive and marked with a thin white halfring, ocellus $\mathrm{R}^{1}-\mathrm{R}^{2}$ more proximal than the others, the band of ocelli accompanied on each side by a more or less continuous olive line bordered with wood-brown; outside the ocelli a row of chocolate spots bordered by an olive-black reversedly crenate line, upon which follows distally a similar but thinner olive-black line, the former line ending in a black clond between $\mathrm{M}^{1}$ and $\mathrm{SM}^{2}$.—Hindwing : a black, slightly chocolate line before middle of cell extending from anterior margin of cell to $\mathrm{SM}^{2}$, curving distad from middle of cell to M, straight in front and behind; an olive-black irregularly crenate line from costal margin to $\mathrm{SM}^{2}$, outside cell, separated by a wood-brown crenate line from a row of more or less strongly arched chocolate spots, spots $\mathrm{SC}^{2}-\mathrm{R}^{2}$ thin, the others broader and continuous ; a large black donble ocellns $\mathrm{C}-\mathrm{R}^{1}$ centred and sprinkled with white, surrounded by wood-brown and olive-black rings, followed behind $\mathrm{R}^{1}$, but within the onter rings, by a small ocellus; a large black ocellus $\mathrm{M}^{1}-\mathrm{M}^{2}$ corresponding to that on upperside; two blind ocelli $\mathrm{R}^{2}-\mathrm{M}^{1}$, kidney-shaped, farther distal than the black ones, marked inside with a bluish white halfring ; these blind ocelli and the posterior black one surrounded together by a wood-brown line; the space between anterior and posterior black ocelli olive-black, slightly streaked with chocolate at veins, the space continuous anteriorly with a chocolate submarginal band which runs parallel with outer margin from $\mathrm{C}$ to $\mathrm{SM}^{2}$, joining before $\mathrm{SM}^{2}$ the chocolate discal band, the submarginal band regularly convex distally between the veins, separated by a wood-brown line from an olive-black reversedly crenate line.

\& similar to $\delta$. Upperside : dise of forewing proximally of pale band much more extended black; black submarginal line of hindwing broad, band-like.

Underside: paler than in $\delta$; forewing with creamy white band in the same position as above, but much narrower and paler, including the last and part of the last but one ocellus.

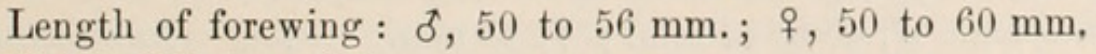

Eight $\delta \delta^{\circ}$, two $q ?$. 


\section{Morphopsis meeki spec. nov.}

§. Body olive-black, slightly chocolate on pronotum and sides of sterna; antenna tawny.

Wings, upperside, olive-black.—- Forewing: hinder margin less roundeddilated than in the other species, long, distal margin almost entire ; a very broad silvery white glossy band from costal margin to hinder angle, not reaching the edges of the wing, widest at $\mathrm{R}^{1}$, being distally angulate at this vein.- Hindwing : a black ocellns $\mathrm{M}^{1}-\mathrm{M}^{2}$ half-way between cell and distal margin, marked inside with a white halfring, and encircled by a pale shadowy ring; two ronnd pale blne spots $\mathrm{R}^{2}-\mathrm{M}^{1}$ at two-thirds from cell to outer margin, centred with a white line ; a tawny orange submarginal band proximally dentate upon the veins, ill defined distally ; distal edge of wing somewhat scalloped.

Underside olivaceons mummy-brown._-Forewing: a pale indistinct bar across middle of cell; a black ocellus $\mathrm{R}^{1}-\mathrm{R}^{2}$ encircled by an indistinct pale ring ; proximally of ocellus a pale line, angulate at $\mathrm{R}^{1}$, ending in a white costal bar ; this line joining before $\mathrm{R}^{3}$ another indistinct line which runs distally of ocellus from costal margin to $\mathrm{M}^{2}$; a reversedly crenate pale submarginal line followed by a straight admarginal one; the pale lines olivaceous bistre, like hindmarginal area from $\mathrm{M}^{2}$ backwards. - Hindwing : abdominal area rufons chestnut; a black donble ocellus $\mathrm{SC}^{2}-\mathrm{R}^{2}$ marked inside with white, encircled by rings of bistre, olive-black, rufous chestnut, olive-black, and bistre ; two separate black ocelli $\mathrm{M}^{1}-\mathrm{SM}^{2}$, marked with white, each encircled by a bistre ring and the two together by rings of oliveblack, rnfous chestnut, olive-black, and bistre; the external bistre rings of the anterior and posterior ocelli connected with one another across $\mathrm{R}^{3}$; to the rings are also joined two lines situated proximally of the ocelli, the anterior line running from costal margin obliquely distad, ending in the bistre ring between $R^{2}$ and $R^{3}$, the second line, convex proximally, emanating from the posterior bistre ring between $\mathrm{R}^{3}$ and $\mathrm{M}^{1}$, joining the ring again behind $\mathrm{SM}^{2}$, the space encircled by this second line chestnut; two small bistre spots $\mathrm{R}^{2}-\mathrm{M}^{1}$ distally of the ocelli, bearing bluish white scaling, the spots representing two more ocelli, being either separate or being connected one with the anterior, the other with the posterior bistre ring; a reversedly crenate submarginal line followed by a straight admarginal one, both bistre-colour.

ๆ. Wings paler on upperside than in $\delta$._- Forewing with rather narrow band from beyond middle of costal margin to apex of $\mathrm{SM}^{2}$, slightly widening behind, yellowish cream-colour in front, gradually becoming orange-buff behind, distal edge of band crenate; a vestige of two black ocelli $\mathrm{R}^{1}-\mathrm{R}^{3}$ just outside the band, bearing some bluish white scales; three bluish white submarginal dots $\mathrm{SC}^{3}-\mathrm{R}^{1}$. - Hindwing essentially as in $\delta$, but fringe cream-colour.

Underside slightly paler than in $\delta$.- Forewing: band as on upperside, but creamy buff, slightly yellowish behind; an indistinct small black ocellns $\mathrm{R}^{1}-\mathrm{R}^{2}$ followed by a vestige of a second ocellus, both situated between the band and a creamy buff line which joins the band before $\mathrm{R}^{1}$; this line angulate at $\mathrm{SC}^{5}$, broken up into spots anteriorly; two faint lines along distal margin slightly paler than the ground-colour.- Hindwing as in $\delta$, but the bistre lines paler, the proximal portion of the outermost bistre rings of the ocelli creamy buff; fringe creamy buff; this colour slightly extending upon wing at apex.

Length of forewing: $\delta$, 40 to $42 \mathrm{~mm}$.; $\uparrow, 45 \mathrm{~mm}$,

Two ơ ठे, one + . 


\section{Erycinidia gen. nov.}

ס. Neuration similar to that of Hypocysta; $\mathrm{M}^{1}$ a very little nearer $\mathrm{R}^{3}$ than $\mathrm{M}^{2}$. Hindwing triangular, being prolonged in the direction of $\mathrm{M}^{2}$, ending in an obliquely rounded lobe. Eye naked.

Only $\delta \delta$ of one species known.

Recalling Lamprolenis G. \& S. (1880) by the shape of the hindwing.

\section{Erycinidia gracilis spec. nov.}

§. Body olive, grey beneath; legs somewhat clayish ; naked parts of antenna ochreous.

Wings, upperside, olivaceous, burnt-umber-brown, hindwing more olive than forewing._ Forewing with a broad shadowy band beyond middle of a deeper brown tint, followed by the vestige of a pale band.-Hindwing with an inconspicnous double admarginal brown line ; a small black ocellus behind $\mathrm{M}^{1}$, centred with a white dot and encircled by a pale brown ring; tail-lobe with some scattered white scales.

Underside drab.—_ Forewing more olive than hindwing, a band before apex of cell, extending from costal edge to M, bordered with olive, and a band on dise grey, the discal band almost straight proximally, gradnally shading off distally, its inner edge crossing $\mathrm{R}^{3}$ one-third the way from cell to distal margin ; three small ocelli $\mathrm{SC}^{5}-\mathrm{R}^{3}$, consisting of a white pupil, an olive ring, a clayish grey one, and again an olive one; ontside the ocelli an undulating olive submarginal line followed by a straight, indistinct, admarginal one.—Hindwing irrorated with whitish scales from base to discal line ; an olive line from costal margin obliquely to near $\mathbf{S M}^{2}$, entering cell just proximally of $\mathrm{R}^{1}$ and leaving it distally of point of origin of $\mathrm{M}^{2}$, the whitish scales slightly condensed near this line; a second line on dise, parallel with the first, contiguous with apex of cell, curved basad at $\mathrm{M}^{2}$, bordered with grey on distal side; a straight row of six small ocelli, in which a white central dot is surrounded by black except in the upper two; two olive lines between ocelli and edge of wing, parallel to wing-edge, somewhat crenate.

Length of forewing : 18 to $20 \mathrm{~mm}$.

A short series of $\delta \sigma^{\sigma}$.

\section{Pieridopsis gen. nov.}

ठ․ Eye naked. Wings short; neuration essentially as in Hypocysta, but discoidal cells of both wings much shorter, that of hindwing being shorter than $R^{3} ; D^{2}$ of forewing angulate, $R^{2}$ originating from below this angle; hindwing triangnlar, being somewhat prolonged in the direction of $\mathrm{M}^{2}$, this vein ending in a short broad lobe, costal margin long.

Type: $P$. virgo.

Allied to Erycinidia, but easily distinguished by the short discoidal cell of the hindwing.

Pieridopsis virgo spec. nov.

ठ 9 . Body olive, hairs on side of meso-metanotum partly white, abdomeu beneath white, palpus clothed with a mixture of white and olive scales.

Wings, above, white._- Forewing: apici-distal area and costal margin black; 
the black colonr entering apex of cell and occupying in $q$ also anterior third of cell (along SC) ; a white costal spot at two-thirds; inner edge of black distal area less sharply defined in $f$ than in $\delta$.- Hindwing : fringe at distal and abdominal margins black; a black admarginal line from $\mathrm{R}^{3}$ backwards, thicker on veins, forming two dots in tail-lobe, a ronnd submarginal dot $\mathrm{M}^{1}-\mathrm{M}$ also black.

Underside of the sexes different (in our single pair); olivaceons black.Forewing of male white from hinder margin forward, this area extending to middle line of cell, sending out a broad belt across cell to costal margin abont $1 \frac{1}{2} \mathrm{~mm}$. from cross-veins, and a narrow band from $\mathrm{M}^{1}$ obliquely to costal margin, this hand being the distal border of a broad black band which extends from costal margin a little beyond $\mathrm{M}^{1}$, being widest in front; four small, ill-defined, oliveblack ocelli $\mathrm{SC}^{4}-\mathrm{R}^{3}$ pupilled with white, the row of ocelli bordered proximally as well as distally by a grey line; parallel with distal edge of wing two rather weak greyish lines contiguous with olive-black ones, the external greyish line very thin. In female the wing washed over with olive-black, the white markings being partly vestigial only, and the white discal area being reduced to a broad stripe along hinder margin.-Hindwing of male : a broad band from shoulder to two-thirds of $\mathrm{M}^{1}$, sinuate behind base of $\mathrm{M}^{1}$, a second band from middle of costal margin to $\mathrm{R}^{3}$, where it joins the first band, the two forming an $Y$; this $Y$ pale yellow, except from costal margin to $\mathrm{SC}$; a row of five vestigial ocelli from $\mathrm{SC}^{2}$ backwards, the white centres being alone distinct; upper two ocelli with feeble white line on proximal side, a distinct white band on distal side of npper three, followed distally by two grey lines, which run from apical to anal angles; tail-lobe black, with creamy scales at base and apex; abdominal fold slightly irrorated with dispersed creamy scales, there being also an irregular creamy streak between $\mathrm{M}^{2}$ and $\mathrm{SM}^{2}$. In female the wing washed over with olive-black, the markings being obliterated for the greater part; two white costal spots distinct; a pale yellow patch on dise beyond cell corresponding to the posterior portion of the $Y$ found in $\delta$; a creamy streak on abdominal fold; ocelli and lines in distal area more or less vestigial, ocellus $\mathrm{M}^{1}-\mathrm{M}^{2}$ black, distinct.

Length of forewing : $\delta$ \& $25 \mathrm{~mm}$.

One pair.

\section{Platypthima gen. nov.}

ơ. Similar to Hypocysta Westw. (1851) and Argyronympha Math. (1886). Eye hairy. Wings short and broad, especially the hindwing; neuration essentially as in Hypocysta.

Type : P. ornata.

\section{Platypthima ornata spec. nov.}

ऽ̊. Body dirty white, palpus and breast clayish and olive-black, antenna ochraceous beneath, tibiae and tarsi more or less clayish ochraceous.

Wings, upperside, olivaceons black.-_-Forewing : a smoky white area from hinder margin forward to point of origin of $\mathrm{M}^{1}$, the area somewhat silvery, extending to base, occupying about half the cell, and reaching distally to three-quarters of hinder margin.—Hindwing : silvery smoky white, except a distal marginal border which measures about $5 \mathrm{~mm}$. in front, narrowing behind, including posteriorly a faint line of deeper olive-black. 
Underside olivaceous mummy-brown.- Forewing deeper brown towards base, with faint traces of white submarginal dots, the vestiges of eye-spots; some indistinct tawny scaling at apex.—Hindwing slightly irrorated with dispersed white scales ; just beyond apex of cell a creamy band widening behind, gradually disappearing in front, washed over with tawny and brown in front and behind; along this light band, on the distal side, a chocolate band, 2 to $3 \mathrm{~mm}$. broad at abdominal margin, gradually narrowing to a thin line which does not quite reach costal margin; a submarginal row of eye-spots, each with white central dot; first spot represented by a white dot surronnded by olivaceous scaling; second and third with traces of rings round the white dot; fourth and fifth black, with an ochraceous ring followed ontwardly by an olive one, this surrounded by a less distinct clayish ring bordered with olive; sixth spot tawny, not ringed; this row of spots accompanied on distal and on proximal side by a narrow metallic vinaceous buff band which is more or less broken at the veins ; distal border of wing divided by a thin brown line into a paler proximal and a darker marginal band.

Length of forewing : $\delta$ i , 18 to $20 \mathrm{~mm}$.

A small series of $\delta \vec{\delta}$, one $q$.

\section{Platyphthima simplex spec. nov.}

8. Body and upperside of wings as in P. ornata; white area of the forewing rather more rounded distally, black admarginal line of hindwing, from $\mathrm{R}^{3}$ backwards, more distinct.

Underside.—Forewing slightly purplish; no vestiges of eye-spots, but an undulating faint line instead, bordered by an olive line distally._- Hindwing rather densely irrorated with scales from base of wing to apex of cell, this area sharply defined, followed by a band-like olive space which is edged with blackish olive distally, this blackish line being contignous with a metallic, somewhat vinaceous, double band in which are situated the ocelli ; ocelli $2,3,4$, and 6 small, olivaceous, with vestiges of rings and distinct white central dot, ocellus 1 vestigial, with the white dot distinct, ocellus 5 large, black, with ochraceons olive rings; metallic band distally bordered by an olive line, upon which follows halfway to edge of wing another olive line.

Length of forewing: 18 to $20 \mathrm{~mm}$.

Two ठิ ठี.

\section{Platypthima leucomelas.}

IIypocysta leucomelas Rotbschild, Nov. Zool. x. p. 309. n. 1 (1903) (Aroa River).

We described this species from a male found by Weiske on the upper part of the Aroa River. A. S. Meek has obtained five more $\delta \delta$, but no $\uparrow$. The insect belongs to the present genus.

\section{Platypthima decolor spec. nov.}

Thongh this species is rather different from the three others of the genus, we do not think it necessary to separate it generically from them.

§. Body olivaceous mummy-brown; a broad lateral line on palpus and a line behind eye creamy ; tibiae and tarsi more or less clayish; femora, breast and underside of abdomen clothed with olive, clay, and grey hairs ; palpus and foreleg mottled with same clay hair-scales. 
Wings above, olivaceous mummy-brown._- Forewing densely hairy in basal half of cell, the hairs directed obliquely backwards; an indistinct band on dise paler than the ground-colour, parallel to distal margin, slightly angulate close to costal margin ; fringe spotted with white, posterior spots indistinct.-Hindwing : $\mathrm{R}^{3}$ and $\mathrm{M}^{1}$ nearer together than in the other species, $\mathrm{D}^{4}$ being less than half the length of $\mathrm{D}^{3}$, and the wing longer posteriorly; vestiges of two ocelli $\mathrm{R}^{3}-\mathrm{M}^{2}$; a faint admarginal double line posteriorly; distal margin scalloped, with white fringespots.

Underside.-Forewing bistre, apex deeper in tint; a narrow creamy band on dise from costal margin beyond $\mathrm{M}^{2}$, elbowed in front; three small ocelli from $\mathrm{R}^{3}$ forward, uppermost largest, each consisting of a white central dot encircled by black, ochreous, deep bistre, and violaceous écru-drab, some chocolate-red scaling near uppermost ocellus; an écru-drab reversedly crenate line from $\mathrm{SC}^{4}$ to $\mathrm{M}^{2}$ followed distally close to margin by a straight ochraceous and tawny line, which is broken at the veins.—Hindwing olive-black, irrorated, with creamy white and chocolate-red scales; a creamy white band from near apex of costal margin to middle of SM${ }^{3}$, irregular, sending ont in cell on proximal side a short spur forward and on distal side a spur backward, this latter spur extending along cross-veins, being hook-shaped, just touching a second cream-coloured band, which is narrow, extending from base of $\mathrm{R}^{3}$ to $\mathrm{SM}^{2}$; four rather large black ocelli, encircled with clayish ochraceous and olive, and pupilled with white, first the largest, $\mathrm{SC}^{2}-\mathrm{R}^{1}$, the others between $\mathrm{R}^{2}$ and $\mathrm{M}^{2}$, vestiges of ocelli $\mathrm{C}-\mathrm{SC}^{2}$ and $\mathrm{R}^{1}-\mathrm{R}^{2}$ also present ; the ocelli proximally and distally surrounded by violaceous écrn-drab bars or rings, which are much broken up ; between ocelli and creamy bands tawny and chocolatered scaling, some reddish scaling also distally of ocelli, especially at apex ; an ochraceous admarginal line contiguous on proximal side with a violaceous écru-drab line, which is reversedly crenate ; the écru-drab markings of fore- and hindwing somewhat metallic, their violet tint changing according to light.

Length of forewing : $20 \mathrm{~mm}$.

One $\delta$.

\section{PAPILIONIDAE.}

\section{Troides chimaera.}

\section{q. Troides chimaera Rothschild, Nov. Zool. xi. p. 311. n. 1. t. 3. f. 25 (1904) (Owgarra).}

The $q$ obtained by A. S. Meek on the present expedition agree with the one figured, l.c.; but the white spots on the forewing vary in size (being often smaller than in the specimen figured, or larger), and the spot in the cell of the hindwing is often absent. The yellow belts of the abdomen also vary much in width.

The of resembles in colour Troides tithonus Deh. (1840), but is otherwise very different.

Eye small, with a vestige of a white border behind. Thorax woolly above and below, with red lateral patch beneath. Abdomen woolly beneath, bases of segments black except dorsally ; these black bands are either continuous from side to side on each segment, being narrow on the sternites, or there are separated dorso-lateral patches on the tergites and round dots at the stigmata; claspers dorsally and eighth tergite mesially fringed with black.

Wings, upperside.—Forewing: neuration as in $q, \mathrm{SC}^{3}$ at or beyond angle of cell, not before that angle as in tithonus, this angle much less obtuse and $\mathrm{M}^{2}$ 
more proximal than in tithomus; distal margin slightly concave, the wing being wider and more triangular than in tithonus; three golden-green areas as in tithonus, the subcostal streak narrower than in that species, streak $\mathrm{SC}^{3}-\mathrm{SC}^{4}$ more or less interrupted, streak $\mathrm{SC}^{4}-\mathrm{SC}^{5}$ longer than in tithomus, and streak $\mathrm{SC}^{5}-\mathrm{R}^{1}$ absent or vestigial, seldom well marked, in which case it does not extend to cell; middle area on the whole narrower proximally than in tithomus, the cell-streak and streak $\mathrm{M}^{1}$ - $\left(\mathrm{SM}^{1}\right)$ being narrower, the area occasionally continued costad distally, joining the subcostal area; fringe with small white spots.- Hindwing shorter and broader than in tithoms, veins $\mathrm{SC}^{2}$ and $\mathrm{R}^{1}$ nearer together, while $\mathrm{M}^{1}$ and $\mathrm{M}^{2}$ are farther apart; much more extended golden-yellow, the discoidal cell being all yellow, except the veins, which are green; the yellow patches $\mathrm{SC}^{2}-\mathrm{R}^{2}$ less produced distad frontally, while cellules $\mathrm{R}^{2}-\mathrm{M}^{1}$ are filled up each by a large golden patch, which is only 2 or $3 \mathrm{~mm}$. short of the thin black distal border of wing ; cellule $\mathrm{M}^{1}-\mathrm{M}^{2}$ much more extended green than in tithomus, bearing often a golden spot at the base; black submarginal spot $\mathrm{C}-\mathrm{SC}^{2}$ small, smaller than spot $\mathrm{SC}^{2}-\mathrm{R}^{1}$, and this a little smaller than (seldom the same in size as) spot $\mathrm{R}^{1}-\mathrm{R}^{2}$; distally of spots $\mathrm{SC}^{2}-\mathrm{R}^{2}$ usually a small golden spot; black distal border very thin, somewhat widening costally.

Underside: the green scaling somewhat golden._-Forewing: green cell-patch as in tithonus, black patch at apex of cell and beyond much smaller than in that species, the green patches $\mathrm{R}^{1}-\mathrm{R}^{3}$ reaching close to cell; the green discal patches each produced distally into a long point midway between veins; black spots within these patches more proximal than in tithonus, spots $\mathrm{R}^{2}-\mathrm{M}^{1}$ standing halfway between cell and distal margin; cellule $\mathrm{M}^{2}-\mathrm{SM}^{2}$ almost entirely green, a broad green streak behind $\mathrm{SM}^{2}$.- Hindwing as above, black border thinner, black submarginal spots slightly larger, the uppermost better defined, cellule $\mathrm{M}^{2}-\mathrm{SM}^{2}$ green, with black patch beyond middle ; hairs upon abdominal fold darker in colour than in tithonus, much less numerous and little over half the length.

Length of forewing : 73 to $85 \mathrm{~mm}$.

A fair series of both sexes was obtained.

\section{Papilio weiskei.}

ठ. Papilio weiskei Ribbe, Inseleten-Börse p. 308 (1900) (Aroa R.).

ठํ. Papilio weiskei, Rothschild, Nov. Zool. x. p. 481. n. 1. t. 11. f. 4. ठ, 5. ㅇ (1903) (Aroa R.).

Among the relatively small series of specimens sent this time by A. S. Meek of this most lovely species there are several $q f$. These agree in colour closely with the $\delta \delta$. The $q$ figured by us from Meek's first collection, the only $q$ obtained during that expedition, was green instead of purple. We do not think that the difference in colour is geographical or depends on the altitude, but believe that we have here to do with another case of individual dichromatism, so very common among Papilio.

\section{PIERIDAE.}

\section{Delias dives.}

o. D! ? a as dices Rothschild, l.c. p. 313. n. 7. t. 2. f. 14 (1904).

We described this fine species from a single male. Mr. A. S. Meek has now sent a good series of both sexes. The $q$ is similar to the $\delta$; the black apical area 
of the forewing, above, is wider, and the hindwing has a broad black distal border, which slightly widens costally. There are often white submarginal dots on both wings, those of the hindwing being slightly pinkish. The white area is feebly yellowish. The sexes are alike on the underside.

\section{Delias microsticha.}

\section{Delias microsticha Rotbschild, l.c. p. 315. n. 8. t. 2. f. 18.19 (1903).}

q. The black borders to the upperside of the wings are broader in the $q$ than in the $\delta$, the forewing bearing a row of white, or yellowish white, submarginal dots and the white area being slightly washed with yellow. The nnderside is variable. Some $q q$ resemble the $\delta$, but there is always a yellowish patch at hinder margin of forewing beyond middle and a vestige of a band across the disc of hindwing. In a second form of the $q$ the cell of the forewing and the whole area behind it are yellow, usually washed with orange; in a third form there is, besides, a sharply defined yellowish white discal band on hindwing, the inner edge of the band being straight and the onter edge curved.

\section{Delias callima spec. nov.}

8. Palpus, a line behind eye, and the breast greenish jellow, npperside of thorax smoky white, abdomen white.

Wings, upperside, white, with a black distal border; this border extending on forewing to near upper angle of cell, the costal edge being all black; on hindwing the border widest in middle, tapering in front and behind, contignous with an ashy grey band, which is the proximal portion of the black border covered with white scaling.

Underside.—Forewing : apical half black, the black colour being more extended than above, entering cell ; a yellow spot just proximally of fork $\mathrm{SC}^{4.5}$, halfmoon-shaped, variable in size, often followed by some more yellow dots which are more distal in position._- Hindwing : black, with a greenish yellow spot at base ; a subbasal streak behind $\mathrm{C}$, reappearing at apex, and a spot in angle $\mathrm{SC}^{2}-\mathrm{R}^{1}$, usually with some smaller spots near it, bluish white, very variable in extent, a patch of whitish blue scales before middle of abdominal fold; between this patch and the white subcostal spot there is a rufescent vermilion band; a second band of the same colour on disc, parallel to distal margin, more or less broken up into halfmoons, spots $\mathrm{C}-\mathrm{SC}^{2}$ the largest, the band variable in width, sometimes reduced to a line, which is occasionally widely interrupted.

+ . Very different from $\delta$. Body more extended greenish yellow.

Wings, upperside._- Forewing: black, basal area washed with white and yellowish green; a chrome-yellow band on disc extending from $\mathrm{SC}^{1}$ to $\mathrm{M}^{2}$, widest in middle, variable in width, last spot rarely absent.-Hindwing washed with greenish yellow from base to apex of cell.

Underside.—Forewing : somewhat greyish at base; base of M white, discal band chrome-yellow, much wider than above, with an additional spot situated behind $\mathrm{M}^{2}$.- Hindwing : as in $\delta$.

Length of forewing : $\delta, 23$ to $28 \mathrm{~mm}$.;,+ 22 to $26 \mathrm{~mm}$.

A series of both sexes. 


\section{Leuciacria gen. nov.}

ð. First segment of palpus longer than second, this longer than third. Club of antenna short, broad, abrupt, sensory grooves extending from base to apex of segments. Apex of forewing somewhat projecting, the distal margin being concave beneath it and then convex, four subcostals; $\mathrm{SC}^{1}$ and $\mathrm{SC}^{2}$ from cell, $\mathrm{SC}^{3}$ absent, $\mathrm{SC}^{4}$ and $\mathrm{SC}^{5}$ on a long stalk, $\mathrm{SC}^{4}$ branching off close to apex of wing, $\mathrm{R}^{1}$ from before middle of $\mathrm{SC}^{5}, \mathrm{R}^{2}$ well below upper angle of cell, $\mathrm{D}^{2}$ being rather more than one-third the length of $\mathrm{D}^{3}$, the latter obtusely angulate below middle, $\mathrm{M}^{2}$ at middle of cell, $\mathrm{M}^{1}$ rather closer to apex of cell than to $\mathrm{M}^{2}$. Hindwing straight proximally at costal margin, the basal lobe very distinct, $\mathrm{SC}^{2}$ branching off at two-thirds from base to $\mathrm{R}^{1}, \mathrm{D}^{1}$ being nearly twice the length of $\mathrm{D}^{2}$, the latter oblique, a little over one-third of $\mathrm{D}^{3}$, this angulate at one-third, $\mathrm{D}^{4}$ over one-half of distal section of $\mathrm{M}$. Clasper of $\delta$ with sharp apical hook curved inwards.

Type : L. acuta spec. nov.

Nearest to that group of "Pieris" to which belongs the African P. pigea Boisd. (1836). In shape resembling a little the larger forms of Elodina.

\section{Leuciacria acuta spec. nov.}

o. Head, pronotum and hairs of palpus olive-black, meso-metanotum and proximal tergites of abdomen greyish black, if viewed from behind, greyish white in frontal view.

Wings, upperside, chalky white, extreme base of forewing, a streak along costal edge to near middle, an apical distal border extending down to $\mathrm{M}^{2}$, tapering to a point behind, its proximal edge curved, crossing $\mathrm{R}^{1}$ in or near middle, and a small basal central patch on hindwiвg black.

Underside glossy.—- Forewing white, slightly washed with yellow, distal marginal band vestigial or absent.—-Hindwing white, distinctly purplish, slightly washed with yellow, a trace of a purple band from base of $\mathrm{M}^{1}$ to $\mathrm{SM}^{2}$; costal edge bright yellow at base, this streak gradually vanishing distally, limited by C.

Length of forewing : 20 to $24 \mathrm{~mm}$.

A series of $\delta \delta$.

\section{ERYCINIDAE.}

\section{Dicallaneura amabilis.}

o. D. a. Rothschild, Nov. Zool. xi. p. 318. n. 21.t. 2. f. 21 (1904) (Owgarra ; non ₹).

The $q$ which we described and figured together with the $\delta$ does not belong to this species. Mr. Meek has now sent a series of $q f$ which agree in the markings of the underside with the $\delta$ of amabilis and are doubtless the true $q f$ of the same. No $\delta \delta$ have come with these $q$ $q$.

On the upperside, the forewing is brownish clay-colour at base, pale ochreous yellow in middle and black in apical two-fifths, the black colour extending along distal margin to hinder angle, being abont $3 \mathrm{~mm}$. wide at $\mathrm{M}^{2}$. The hindwing is brownish clay, with an ochraceous patch at costal margin, and the usual brownish black submarginal spots. On the underside the forewing is creamy buff in middle, a line running from inner edge of chocolate distal area into the creamy area, the line terminating at $\mathbf{M}^{2}$. 
16. Dicallaneura leucomelas spec. nov.

+. Dicallaneura amabilis Rothschild, l.c. t. 2. f. 22 (1904) (Owgarra; non ठ).

The present collection of A. S. Meek proves that we were wrong in associating this insect, which has a white and olive-black npperside, with the preceding one. The two $\delta \delta$ and four $q$ ontained in the present collection leave no donbt about its being a distinct species. The sexes are practically identical. The wings of the $f$ are rather broader than in the $\delta$, the tail is wider, the white area of the forewing and the costal patch of the hindwing are a little larger, and the groundcolour of the underside is slightly paler. For further details see descriptions and figure of + , l.c.

Type : $\delta$.

\section{LYCAENIDAE.}

\section{Hypochrysops meeki spec. nov.}

§. Palpus grey, black at apex and above, with chestnut scales on side. Frons and occiput black, the former with two cinnamon-rufous vittae and along eye a grey line, a belt behind eyes cinnamon-rufous ; thorax above blackish olive-green, slightly bluish ; abdomen black, with violet reflections; underside of thorax and abdomen clayish grey, sides of breast somewhat ferruginous. Foretibia with thorn at apex.

Wings, above, black._- Forewing bright metallic blue from base to disc, this area extending anteriorly to middle of cell and being at $\left(\mathrm{SM}^{1}\right)$ about $2 \mathrm{~mm}$. short of distal margin._- Hindwing also with a brilliant blue basi-discal area, which is shot with purple in front and behind as well as distally between the veins, the area being expanded between $\mathrm{SC}$ and $\mathrm{SM}^{2}$, reaching rather close to distal edge; fringe of both wings more or less dirty grey, except at tips of veins.

Underside of hindwing and costal and apical areas of forewing cinnamonrufous._- Forewing smoky grey at hinder margin and ochraceous from $\left(\mathrm{SM}^{1}\right)$ forward to lower angle of cell ; two lines along $\mathrm{SC}$ and another in middle of cell greenish or bluish silvery, the mesial cell-line curved backwards at apex; a row of five submarginal dots of the same metallic colour standing at the distal side of minute black dots; between this row and the cell the following metallic spots: four minute dots $\mathrm{SC}^{3}-\mathrm{SC}^{4.5}$, three rather larger dots $\mathrm{SC}^{4.5}-\mathrm{R}^{1}$, a bar $\mathrm{R}^{1}-\mathrm{R}^{3}$ near cell and another bar near submarginal dot, a bar $\mathrm{R}^{3}-\mathrm{M}^{1}$ proximally of outer bar $\mathrm{R}^{1}-\mathrm{R}^{3}$; basal area blackish from cell backwards._Hindwing with numerous metallic bars bordering cinnamon-rufous spots of a deeper tint than the groundcolour, the bars greenish silvery as on forewing: four bars $\mathrm{C}-\mathrm{SC}^{2}$, with a clayish bar between the first and second and again between the third and fourth, two bars $\mathrm{SC}^{2}-\mathrm{R}^{1}$, with a clayish bar between them; eight bars in cell and between $\mathrm{R}^{1}$ and $\mathrm{R}^{3}$, the first double, a clayish bar proximally of last; two bars $\mathrm{R}^{3}-\mathrm{M}^{1}$, with a clayish one in between; three bars $\mathrm{M}^{1}-\mathrm{M}^{2}$, with a clayish one at base and another between second and third; eight bars $\mathrm{M}^{2}-\mathrm{SM}^{2}$, the most distal but one partly clayish, all continuous with the bars in front of them; six bars $\mathrm{SM}^{2}-\mathrm{SM}^{3}$, partly edged with black; the submarginal bars form an interrupted line, while the other bars stand partly on the interspaces of the bars which are situated before and behind them; an oblique metallic line at base before $\mathrm{C}$.

․ Not known.

Length of forewing : 14 to $16 \mathrm{~mm}$.

A series of $\delta \delta$. 
18. Deudorix grandis spec. nov'.

๙. Frons and palpus yellowish green, occiput and sides of sterna bice-green ; thorax above and abdomen olive, greenish in front, sterna and abdomen beneath with orange middle stripe.

Wings, upperside.—Forewing black; fringe greenish; a bright metallic blue patch from near base to apex of cell, extending from middle of cell to hinder margin, remaining about $5 \mathrm{~mm}$. short of outer margin at $\mathrm{SM}^{2}$. - Hindwing greenish black, fringe paler, abdominal edge bice-green, longest scales of fringe and tip of tail white; some blue scales on cross-veins, occasionally absent.

Underside bice-green, slightly washed with ochraceous, especially in submarginal area of hindwing._- Forewing : a bar on cross-veins and a band on disc olive-green, bordered with grey, the band gradually narrowing behind, straight, feebly undulating; a marginal band deeper bice-green than rest of wing, limited proximally by a rather indistinct grey line and separated from fringe posteriorly by a pale green line; posterior area of wing greyish bice-green.-Hindwing: a bar on cross-veins and a discal band of the same colour as the markings on forewing, the band straight from costal margin to $\mathrm{Mi}^{2}$, then curving to middle of abdominal margin, some black scales beneath the green ones in the band, the posterior portion of the band distinctly blackish; between discal band and distal margin a shadowy green band separated by a greyish line from a submarginal band of an ochraceous green colour; this submarginal band separated from fringe by a greenish creamy line; two black submarginal dots $\mathrm{M}^{1}-\mathrm{SM}^{2}$; partly covered by bluish white scales; anal lobe black, some bluish white scales at its apex and a spot of greenish white ones posteriorly at its base.

+ . Body as in $\delta$, head and palpus purer bice-green, orange stripe broader on underside of abdomen, narrow and greenish yellow on breast.

Wings, upperside._- Forewing greenish black; fringe pale green; a white patch extending from hinder margin forward to $\mathrm{R}^{2}$, not entering cell, neither reaching base nor hinder angle._-Hindwing white for the greater part; base greenish black; abdominal margin bice-green; a submarginal band greenish black, widest in front, measuring abont $4 \mathrm{~mm}$. at $\mathrm{SC}^{2}$, separated from edge of wing by a white line from $\mathrm{SC}^{2}$ to anal lobe.

Underside much purer bice-green than in $\delta$, paler proximally than distally.

Forewing: the white area extending farther costad than above, the green discal band bordered white; a white submarginal line._Hindwing : markings as in $\delta$, but green discal band thinner, and accompanied on each side by a white band, both white bands stopping at $\mathrm{M}^{2}$, the proximal one much narrower than the distal one and not quite reaching costal margin.

Length of forewing: $\delta, 25$ to $28 \mathrm{~mm}$; $\uparrow, 21$ to $30 \mathrm{~mm}$.

A small series of both sexes.

\section{Stilbon meeki spec. nov.}

§. Body olive-black, with a broad clayish grey mesial stripe on underside; frons edged with grey.

Wings, upperside._Forewing velvety black, a distal marginal band from $\mathrm{R}^{1}$ backwards cyaneous when the eye is between specimen and light.-Hindwing black down to lower angle of cell, basal third of abdominal area olivaceous; rest of wing inclusive of tail orpiment-orange; anal lobe with black spot bearing some bluish scales. 
Underside olive, slightly purplish._-Forewing with ten grey lines: first subbasal, from costal edge to M, second and third from M to $\mathrm{SM}^{2}$, broken on M, approximate at $\mathrm{SM}^{2}$, interspaces between these lines olivaceous black; fourth and fifth lines from costal edge, where they are widened, to $\mathrm{M}^{2}$, with olivaceous black interspace; sixth line thin, contignous with fifth at costal margin, extending to $\left(\mathrm{SM}^{1}\right)$, here meeting the seventh line, interspace an olivaceous black band which gradually narrows behind; eighth line thin, interspace greyish; ninth parallel to outer margin; tenth thin, situated at edge of wing._- Hindwing with similar grey lines and blackish bands as on forewing; four oblique lines from $\mathrm{C}$ to $\mathrm{M}$ and $\mathrm{R}^{3}$, followed distally by two more lines, a grey ring at cross-veins; anal area paler than above, much less sharply defined, produced to base in the direction of $\mathrm{M}^{2}$, this projection band-like, pale salmon-buff; two orange spots within anal area, not very distinct, being remnants of a discal band; black spot on anal lobe bearing a metallic blue spot proximally and distally; two black submarginal spots $\mathrm{M}^{1}-\mathrm{SM}^{2}$ bearing each a blue bar ; submarginal spots $\mathrm{R}^{2}-\mathrm{M}^{1}$ vestigial.

Length of forewing : $20 \mathrm{~mm}$.

One $\delta$.

\section{SATURNIIDAE.}

Eurhodia gen. nov.

ๆ. Antenna bipectinate to apex, distal branches of middle segments a little over half the length of proximal branches. Fourth foretarsal segment with slender spine at each side on ventral side. Stem $\mathrm{R}^{1.2}$ of forewing nearly as long as branch $\mathrm{R}^{2}$; $\mathrm{R}^{3}$ and $\mathrm{M}^{1}$ separating halfway between base of wing and tip of $R^{3}, R^{3}$ much longer than $R^{1}$, the point of separation of $R^{3}$ and $M^{1}$ lying a good distance proximally of transparent spot, as is the case also on hindwing; discoidal cell completely open on both wings ; oblique cross-vein $\mathrm{D}^{1}$ of hindwing longer than the cell is broad.

Close to Rleodia, but distinguished by the details mentioned.

Type: E. gyra spec. nov.

\section{Eurhodia gyra spec. nov.}

\section{f. Body ferruginous, antenna and tarsi black.}

Wings, upperside, cinnamon-rufons, ferruginous at base, streaked with pale orange on the veins.-Forewing: an olive-black band across cell, distally of $\mathrm{M}^{2}$, curved ; another black curved band proximally of $\mathrm{M}^{2}$ between cell and hinder margin ; a transparent spot at two-thirds, quite circular, proximally bordered by an indistinct vinaceous-red halfmoon, and distally by a blackish halfring ; an olive-black band just ontside transparent spot from five-sixths of costa to three-fourths of hinder margin, faintly curved costad in front; between this band and distal margin a reversedly crenate greyish white band imperfectly separated by olive-black scales into two lines, the band ending in a white apical spot._Hindwing: an evenly curved olive-black line before middle from $\mathrm{C}$ to abdominal margin, bordered proximally by a pale orange band; a small transparent spot at two-thirds, bordered proximally by vinaceous-red and olivaceous halfrings and distally by an olive-black halfring bearing some vinaceons-red scales; an olive-black undulating line distally of eye-spot but separate from it, 
parallel to outer margin, followed distally by a similar greyish white line ending in a white apical patch; the olive-black bands and lines rather obscure on both wings.

Underside similar to upper, the olive-black markings replaced by vinaceous cinnamon-rufous ones; hindwing with subbasal orange-yellow band from C to hinder margin, forming a halfring, which is open proximally, bordered distally by an obscure vinaceous cinnamon-rufous band; no further bands between these and the eye-spot.

Length of forewing: $30 \mathrm{~mm}$.

One + .

GEOMETRIDAE.

\section{Milionia pericallis spec. nov.}

ऽ $\uparrow$. Body velvety black; head, pronotum, and legs metallic blue, strongly glossy, sides of abdomen also glossy at base, rest of body with blne reflections; abdomen with orange patch of variable size on underside in distal half.

Wings, upperside, velvety black, with blne reflections.-_-Forewing: rather more elongate in $\delta$ than in $q$; a broad greenish blue metallic band from costal to hinder margin, variable in width, extended basad at costal margin in $\delta$, its distal edge crossing cell usually at point of origin of $\mathrm{M}^{1}$; a submarginal band of elongate blue spots from costal margin to $\mathrm{M}^{2}$ narrowing behind.-Hindwing strongly notched in $\delta$ before anal angle, the notch vestigial in $q$; a broad metallic-blue patch from base beyond apex of cell, triangular, widening distally, a little longer in $q$ than in $\delta$; vestiges of blue submarginal spots, often absent; proximally of anal angle a rounded spot of deep crimson, very variable in size, often absent.

Underside black, with blue reflections in $\$$; scales raised in $\delta$ in distal half of wing, intermingled with hair-like scales, between veins large opaque patches, rather indistinct, opaque appearance due to presence of grey scales.—-Forewing: metallic blue from base to disc, the blue area extended to near distal margin at $\mathbf{M}^{2}$, limited behind at $\left(\mathrm{SM}^{1}\right)$, reaching at costal margin a little beyond apex of cell, usually more extended in $q$ than in $\delta$.- Hindwing: metallic blue from base to near apex of cell in $\delta$, the area deeply excised behind cell, in $?$ the blue colour extending beyond cell, the area being uniformly blue in and before cell, but more black with blue reflections behind cell; a black spot on cross-veins in $q$; red spot as above, rather paler and larger.

Length of forewing: ơ,+ 22 to $26 \mathrm{~mm}$.

A series.

\section{Milionia callima spec, nov.}

8 9 . Sexes dissimilar. Body and legs black, with a very strong metallic greenish blue gloss.

Wings blue-black above, the of more blue than the $q$; forewing in $\delta$ with a metallic greenish blue basal area from $\mathrm{SC}$ to hinder margin, the area triangular, widest behind, reaching to two-thirds of hinder margin; in $q$ a slightly curved band of the same colour from costal to hinder margin, reaching the latter just before angle, including the discocellulars, a few blue scales at base of wing.-Hindwing: similar in shape in the sexes, with the distal margin 
rounded; uniform in colour in $\delta$, rather less blue proximally than distally; in $q$ a few metallic greenish blue scales on disc indicating a discal band.

Underside velvety black in $\delta$, somewhat bluish; a metallic greenish blue band obliquely across forewing from costal margin to apex of $\mathrm{SM}^{2}$, occupying apical half of cell, widest between $\mathrm{M}^{1}$ and $\mathrm{M}^{2}$, its last partition triangular; a metallic line from band along SC to near base; in $q$ the band more distal anteriorly, including the cross-veins, therefore less oblique than in $\delta$ and its outer edge not incurved before $R^{3}$. - Hindwing with a metallic greenish blue costal streak at base, in $\delta$ a large rounded patch of modified scales at apex, the scales being hairlike and directed backwards.

Hindtibia of $\delta$ broad, spurs very short.

Length of forewing: $\delta \uparrow, 22 \mathrm{~mm}$.

Three $\delta \delta$, one $q$.

\section{Milionia aglaia spec. nov.}

of $q$. Sexes similar. Body and legs metallic greenish blue, very glossy.

Wings blue-black above, more blue in $\delta$ than in $f$ - Forewing with an oblique band from costa to hinder margin, slightly angulate behind $\mathbf{M}^{2}$, starting at costa proximally of cross-veins in $\delta$, but including cross-veins in $q$, and ending at hinder margin abont $3 \mathrm{~mm}$. from angle; the band usually all red, but sometimes yellow except posteriorly; a broad red streak between base and band along hinder margin, often extended to the band, merging together with it. Hindwing with red band on disc well ontside cell, variable in length and width, either irregularly denticulate or even.

Underside black, with glossy metallic greenish blue basal streaks, one on fore- and two on hindwing; bands as above, yellow, more or less washed with red; no red or yellow streak along hinder margin of forewing.

Length of forewing : $\delta$ \% 25 to $27 \mathrm{~mm}$.

A series of $\delta \delta$, two $q$ ?

\section{Craspedosis cyanea spec. nov.}

ð. Body and legs black, with blue reflections.

Wings, upperside, blue-black.—-Forewing with broad metallic blue band extending from fovea to point of origin of $\mathrm{M}^{1}$. - Hindwing deep blue in side-light, somewhat glossy from base to disc.

Underside bluish black, both wings glossy blue from base to disc.

Length of forewing: 18 to $21 \mathrm{~mm}$.

Two ơ ठे.

\section{Craspedosis desmiata spec. nov.}

ठ․ Body olivaceous black, with blue reflections on upperside.

Wings, upperside, mummy-brown, somewhat metallic, with faint purplish reflections in $\delta$, apical area of forewing slightly more black; a broad cadminmorange band across forewing from middle of costal margin to hinder angle, the fringe remaining black, the band of nearly even width, feebly narrowing behind.

Underside olive-black, with purplish reflections, band on forewing as above, rather paler.

Length of forewing: $\delta$ \% 16 to $20 \mathrm{~mm}$.

A small series. 


\section{ARCTIIDAE.}

\section{Eriomastyx gen. nov.}

8. First antennal segment very long, as in Chamaita Walk. (1862). C of forewing connected with costa by several veinlets, as in Schistophleps Hamps. (1891) ; four subcostals, $\mathrm{SC}^{1}$ anastomosed with $\mathrm{C}, \mathrm{SC}^{2}$ on a stalk with $\mathrm{SC}^{1}$ in $\delta^{8}$,

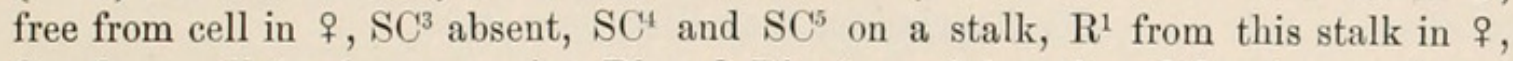
free from cell in $\delta$, cross-veins $\mathrm{D}^{2}$ and $\mathrm{D}^{3}$ of equal length and forming an obtuse angle directed distad in $\delta, \mathrm{R}^{1}$ from this angle, in $+\mathrm{D}^{2}$ and $\mathrm{D}^{3}$ (or the vein homologous to the two combined) also angulate together, but the angle directed basad, $\mathrm{M}^{2}$ from middle of cell in $\uparrow$, from before middle in $\delta, M^{2}, M^{1}, R^{3}$ and $R^{2}$ nearly equidistant from one another, $\mathrm{D}^{3}$ and $\mathrm{D}^{4}$ in the direction of $\mathrm{M}$, appearing as prolongation of that vein, as in Papilionidae. $\mathrm{SC}^{2}$ and $\mathrm{R}^{1}$ of hindwing on a long stalk in $q$, on a very short stalk in $\delta$, the wing small in $\delta$, with broad scent-fold between costal edge and cell, the latter being narrower and $\mathrm{C}$ and $\mathrm{SC}^{2}$ incurved. In $\delta$ foretibia rednced; foretarsus thin, long, filiform; midfemur densely clothed on outer side with long thin hairs bearing each at end an ovoid vesicle, these clubbed hairs resembling the stalked eggs of Hemerobius.

Type: E. latus spec. nov.

The genus differs from Schistophleps in the long first antennal segment, besides neuration ; from Caulocera in the long antennal segment and the presence of costal veinlets; from Chamaita in neuration.

\section{Eriomastyx latus spec. nov.}

§. Head and thorax yellowish buff, antenna, legs, and abdomen creamy, incrassate apices of midfemoral hairs pale tawny.

Wings transparent; upperside.—Forewing broad, only half as long again as broad, costal margin strongly curved, yellowish buff, the colour most distinct at base and hinder margin; a subbasal line, widening behind cell into a large patch, another line from costal margin across apex of cell to middle of hinder margin, and a deeply crenate line on disc purplish, indistinct; a dot in middle of cell and another on discocellular black._-Hindwing paler than forewing.

Underside without markings.

. Paler than $\delta$, abdomen almost white; purplish lines of forewing just vestigial.

Length of forewing: $\delta \uparrow, 11 \frac{1}{2} \mathrm{~mm}$.

One $\delta$, four $\uparrow q$.

\section{Asura rhodina spec. nov.}

§. Body flame-scarlet; abdomen and mid- and hindlegs buff; antenna bipectinate.

Wings, upperside._-Forewing flame-scarlet, a subbasal band, costal margin, distal veins and fringe yellow, a large olive patch occupying more than central half of wing, bisinuate costally, trisinuate distally and unisinuate behind.Hindwing pale rose-pink, with yellowish or buffish grey tinge; $\mathrm{C}$-close to apex of cell, $\mathrm{R}^{2}$ and $\mathrm{R}^{3}$ on a very short stalk, $\mathrm{M}^{1}$ before apex of cell.

Underside rose-pink, forewing washed with scarlet.

. Much larger than $\delta$ and much paler; antenna simple, with bristles; C of 
hindwing more proximal than in $\delta, \mathrm{R}^{2}$ and $\mathrm{R}^{3}$ on a long stalk, $\mathrm{N}^{1}$ from angle of cell ; anal tuft blackish olive; olive area of forewing extending to costa, the two costal sinnses deep, especially the proximal one, which reaches beyond $\mathrm{M}^{1}$.

Length of forewing: $\delta, 7$ to $8 \mathrm{~mm}$.; $q, 11 \mathrm{~mm}$.

A series of $\delta^{\circ} \delta$, two $q$.

\section{Caprimima metallica spec. nov.}

\&. Body blue-black, head and thorax strongly glossy, abdomen less glossy : forecoxa, foretibia, first foretarsal segment except base, apex of midfemur and midtibia and of first tarsal segment, greater portion of hindfemur and hindtibia, an apical spot on first hindtarsal segment, apex of mid- and hindcoxae, a spot at base of mesothoracical tegula and the antevaginal tuft white.

Wings, upperside.—Forewing glossy blue; a purplish orange spot at apex.-Hindwing white, with a broad blne-black border at distal and abdominal margins, half as wide again at apex as at anal angle, but remaining here as wide as at abdominal margin.

Underside blue-black, slightly glossy._- Forewing broadly blnish white at base, this area continued in cell to lower augle; orange spot at apex slightly larger than above.-Hindwing as above, the blue-black border a little narrower, especially before anal angle.

Length of forewing : $10 \mathrm{~mm}$.

Two $+q$.

\section{Caprimima aenea spec. nov.}

. Head and upperside of thorax blackish green, metallic, abdomen blue-black, feebly glossy; legs a little more extended white than in metallica; antevaginal tuft white.

Wings, upperside.—Forewing like thorax; three white spots, first transverse, a little nearer base than $\mathrm{M}^{2}$, reaching neither costal nor hinder margin, second rounded, at upper angle of cell, third subapical, small, subdivided by $\mathrm{R}^{1}$, an orange-purple spot between second and third white spots.-Hindwing bluish black, a large white patch from costal margin to $\mathrm{SM}^{2}$, obliqne, black distal area more than twice as wide at costal margin as at $\mathrm{SM}^{1}$, but here surpassing in width the abdominal area.

Underside blue-black, not metallic, white markings somewhat larger than above, especially the subbasal spot of forewing.

Length of forewing : $10 \mathrm{~mm}$.

Four $q$ \%

\section{Neoscaptia albata spec. nov.}

ठ. Body black, head and upperside of thorax metallic blue, abdomen slightly blue; palpus and legs luteons, the scaling of the latter partly blue, especially on foreleg; apex of hindfemur, basal half of hindtibia, and the greater part of the first segment of the tarsi, as well as a large patch laterally on mesosternum, white; claspers creamy.

Wings, upperside: venation distorted on account of a scent-organ ; costal margin of forewing turned up, fringed with long scales lying backwards, cell strongly reduced in width, a large subbasal fovea on fore- and hindwing, convex 
above on fore-, below on hindwing.-Forewing: base blne, a broad subbasal band white, contiguous with a broad purplish blue band which is constricted in middle; disc purplish orange; apex and distal and costal edges black, metallic purple, strongly glossy in side-light; a white subapical dot.—Hindwing white, bordered with olive-black at distal and abdominal margins, the border widest at apex, very thin at anal angle.

Underside as above, no blue metallic gloss ; the blue bands of forewing partly replaced by olive-black ones; fovea of forewing glossy white-grey, that of hindwing olive-black.

$\uparrow$. Like $\delta$; anal tuft smoky grey above, white beneath; white band of forewing broader than in $\delta$, with a thin blue distal border, black distal and costal borders thin, hardly wider at apex than at hinder angle.

Length of forewing: $\delta$ \&, 9 to $10 \mathrm{~mm}$.

Two of $\delta$, three $q$ ? .

\section{Neoscaptia aequalis spec. nov.}

ठ. Similar to N. albata; head and upperside of thorax dark metallic green-blue.

Wings, above. - Forewing like head and thorax ; costal fold as in N. albata, also the fovea on fore- and hindwing; a small white spot behind costal fold well before middle, with some white scales in front of it at edge; an ill-defined discal band from costal margin to hinder angle, purple-orange, much shaded with metallic green-blue scales, especially in middle-_-Hindwing purple-black, with a large white basi-discal area, subtriangular, smaller than in $N$. albata.

Underside purplish olive-black._-Forewing : a small white streak at base ; subapical white dot as above, proximally of this dot a conical longitudinal orangetawny spot.—Hindwing as above, costal edge white in front of fovea.

ๆ. Like $\delta$. Forewing with white subbasal spot above, very variable in size, and a large white basal patch below ; tawny-orange spot rounded above, about three times the size of the white one, vestigial below; white area of hindwing rather larger than in $\delta$.

Length of forewing : $\delta$ \% , $9 \mathrm{~mm}$.

\section{Neoscaptia leucodera spec. nov.}

§. Head and npperside of thorax metallic green-blne, rest of body olive-black, slightly purplish ; collar with two white spots ; a lateral patch on breast, and basal half of the first segment of the tarsi white ; claspers creamy.

Wings, upperside.—- Forewing : costal fold as in N. albata, but smaller, no fovea on fore- or hindwing ; metallic green-blue like thorax ; a subbasal band from costal fold straight to hiuder margin preceded by a dot on costal fold, and a ronnd subapical spot, white; proximally of subapical spot a purplish orange patch, obliquely ovate, from $\mathrm{SC}^{3}$ to $\mathrm{M}^{2}$.— Hindwing olive-black, with a bluish sheen; a large white triangular area from costal margin to $\mathrm{SM}^{2}$, the black distal border being $1 \frac{1}{2} \mathrm{~mm}$. broad at $\mathrm{SM}^{1}$.

Underside olive-black, slightly purplish._-Forewing : a white streak from base to apex of cell; orange spot smaller and white subapical spot larger than above.-Hindwing : white area larger than above.

$\uparrow$. Like $\delta$; apex of hindfemur and basal half of hindtibia white, in addition to the first tarsal segment, the collar, a lateral patch on mesosternum and the 
antevaginal tuft; white spots on wings somewhat variable, snbbasal one of forewing rather smaller than in $\delta$, purple-orange spot also smaller.

Length of forewing: $\delta$ \% , $9 \mathrm{~mm}$.

One $\delta$, two $q ?$.

Resembling in colour $N$. aequalis, but easily distinguished by the white collar, and, in $\delta$, by the different scent-organ.

\section{Neoscaptia poecila spec. nov.}

†. Head and upperside of thorax metallic purplish blue, rest of body and legs olive-black, with slight purple reflection; collar with two contiguous white spots as in $N$. leucodera ; legs without white, antemarginal tuft whitish grey.

Wings, upperside.—Forewing narrow, $\mathrm{R}^{3}$ and $\mathrm{M}^{1}$ stalked together ; metallic purplish blue from base to middle, this area sinuate distally, followed by a large tawny-orange discal patch, which does not quite reach costal or hinder margin, bordered with metallic purplish blue; this border dentate ; distal margin, costal edge, and fringes black; a central subbasal spot white-_-Hindwing more triangular than in the other species, the apex being less rounded; olive-black, slightly purplish; a large white basal patch from costal margin to $\mathrm{SM}^{2}$, its outer edge crossing $\mathrm{M}$ at base of $\mathrm{M}^{2}$; black abdominal border narrow from middle to base.

Underside olive-black, purplish; forewing with a white subbasal patch shaded with olive; an orange-tawny subapical lougitudinal patch; white area of hindwing as above.

Length of forewing: $9 \mathrm{~mm}$.

One + .

\section{AGARISTIDAE.}

\section{Burgena constricta spec. nov.}

?. Similar to B. varia Wlk. (1854); thorax, abdomen, and wings different in pattern. Anterior half of collar orange, posterior black. Mesonotum black in centre, orange behind ; tegula orange, with an oblique black line joining anteriorly at side the black belt of pronotum. Abdominal tergites 1 to 6 black at base, orange at apex, 7 black, with the anal tuft orange; abdominal sternites 1 to 6 orange, 7 black, with a few orange scales, a few black scales in centre of 5 , anal tuft all orange.

Wings, upperside._- Forewing shorter and broader than in B. varia, $\mathrm{SC}^{5}$ more distal; a basal streak before cell and a subbasal spot in cell yellowish white ; postmedian cell-spot longer transversely than in varia, orange-yellow basal streak situated along $\mathrm{SM}^{2}$ broader than in varia, parallel to hinder margin, not to costal margin._-Hindwing: yellow area paler orange than in varia, deeply constricted in middle, the cell being entirely black.

Underside._Markings of forewing yellowish white._Hindwing : a basal costal patch sulphur-yellow, separated into streaks by the blackish veins; yellow area constricted as above, but the posterior patch enlarged basad, filling up the area between cell and abdominal edge, some scattered scales near base and part of $\mathrm{SM}^{2}$ remaining black.

Length of forewing : 22 to $24 \mathrm{~mm}$.

Two + \% 
35. Argyrolepidia palaea spec. nov.

$\delta$. Head olive-black above ; a line behind eye and ill-defined spots on frons white. Palpus olivaceous black, first segment and a dorsal line on second yellow, second segment irrorated with white scales. Thorax above purplish olive-black, collar not edged with white, but marked with some orange at side; breast and femora orange, tibiae and tarsal segments tipped with white, a small white spot in middle of tibiae. Abdomen olivaceons black, with bluish reflections, the segments edged with bluish white ; claspers of $\delta$ with pale yellow hair-scales ; last sternite (7th) of $q$ unicolorons, olivaceous, black.

Wings, upperside.—Forewing brown, strongly purplish, a spot beyond middle of cell and a band on disc whitish, vestigial; a few scales at base and some beyond the vestigial discal band violet-blue; fringe black.—Hindwing black, with moderately strong blue gloss, a large central patch light blue, metallic, oblique, produced basad in front; a white marginal spot behind $\mathrm{M}^{2}$.

Underside purplish black._- Forewing: a dot in cell and a band on disc bluish white, with some blue scales at the edges, the band extending from $\mathrm{C}$ to $\mathrm{M}^{2}$, slightly narrowing costad, not interrupted, feebly curved; a patch at base situated in and before cell pale blue.-Hindwing : a pale blue patch at base about twice as wide between lower angle of cell and abdominal margin as between lower angle of cell and costal margin, the posterior portion extending about $3 \mathrm{~mm}$. beyond angle of cell; outside this area a widely interrupted blue band $(\delta)$ or two blue spots ; a white marginal spot as above, but larger ; no white spot in centre of wing.

Length of forewing: $\delta$ o 18 to $22 \mathrm{~mm}$.

One $\delta, 2$ \& $q$; type: $q$.

\section{Argyrolepidia lunaris spec. nov.}

$\delta$ \&. Similar to A. palaea. Frons more extended white; breast and femora paler yellow; tibiae and first tarsal segment densely irrorated with white; last abdominal sternite of $q$ fringed with yellow.

Wings, upperside.—Forewing: metallic blue markings more numerous, white cell-spot and discal band more distinct, the band narrow in front, wider behind, interrupted at the veins, ending at costal edge in a blue dot; a white marginal spot just below apex._- Hindwing glossy blue, appearing black in certain positions, white patch ontside cross-veins, obliquely halfmoon-shaped, encircled with metallic blue, this blue scaling extending to base of wing and present also along $\mathrm{SM}^{2}$; a white marginal spot below apex, and usually several other white marginal spots farther back.

Underside bluish or purplish black._-Forewing : cell-spot rectangular; discal band not broken up, bnt angulate at $\mathrm{R}^{2}$; a metallic pale blue basal patch. Hindwing : a metallic pale blne basal area as in meeki; a white central spot as above, separated from the blue area by a black interspace, except behind, where the blue scaling which encircles the white spot is continuous with the blue area; fringe-spots as above, the additional dots more distinct; a minute blue dot on disc behind $\mathrm{SC}^{2}$.

Length of forewing: $\delta$ \&, 21 to $22 \mathrm{~mm}$.

Three ơ $\delta$, one + . 


\section{NOCTUIDAE.}

Eucocytia gen. nov.

$\delta \uparrow$. Palpus hardly reaching frons in $\delta$, a little longer in $q$ than in $\delta$, slightly porrect, third segment minute, second shorter than first. Eye hairy. Antenna clubbed, a little compressed, the same in both sexes, club a little wider in o than in $q$, slightly thinning at apex, which is obtuse ; scaly area of antenna restricted to a narrow stripe, scaling smooth, non-scaled surface densely covered with minute hairs, some very short sensory bristles at apex of each segment. Hindtibia somewhat incrassate; tibial spurs short, being about as long as the tibia is broad, external spur a little longer than inner; two pairs to hindtibia.

Neuration : forewing with areole, $\mathrm{SC}^{1}$ free, $\mathrm{SC}^{2}$ and $\mathrm{SC}^{5}$ from areole, $\mathrm{SC}^{3}$ and $\mathrm{SC}^{4}$ stalked together, $\mathrm{R}^{1}$ from upper angle of cell, $\mathrm{R}^{2}$ and $\mathrm{R}^{3}$ close together, from lower angle, $\mathrm{M}^{1}$ a little before angle : hindwing, cell about two-thirds the length of wing, $\mathrm{SC}^{2}$ and $\mathrm{R}^{1}$ from upper angle, $\mathrm{R}^{1}, \mathrm{M}^{1}$ and $\mathrm{M}^{2}$ from lower angle, close together, but separate, $\mathrm{M}^{2}$ from three-fifths of cell.

Type : E. meeki spec. nov.

\section{Eucocytia meeki spec. nov.}

$\delta q$. Head and underside of thorax woolly, black, the wool on metanotum, abdomen, and legs also black, smooth scaling of abdomen and legs metallic glossy blue, purplish ; pro- and mesonotum, except base of femur, carmine ; claspers of $\delta$ also carmine.

Wings, upperside.—Forewing: distal margin convex before middle, costal margin convex at base, then slightly concave to near apex; black-blue, a broad metallic blue band at base, a broad metallic golden green band from costa to near hinder margin, narrowing behind, produced distad upon the veins, its inner edge slightly curved, crossing $\mathrm{M}$ between $\mathrm{M}^{1}$ and $\mathrm{M}^{2}$, or at base of $\mathrm{M}^{1}$. - Hindwing somewhat shorter in $\delta$ than in $q$, rounded at apex ; slightly emarginate before anal angle, black-blue, metallic greenish blue distally.

Underside metallic greenish blue, purple at hinder margin of forewing, a broad central stripe on both wings of $\delta$ black from near base to near distal margin, the scales being suberect and directed forward.

Length of forewing: $\delta, 25 \mathrm{~mm}$. ; $\uparrow, 30 \mathrm{~mm}$.

One pair. The $f$ was obtained during the first expedition to Owgarra.

38. Buzara calodesma spec. nov.

đ̊. Sexes similar; body and legs black, rather slightly metallic blue, somewhat woolly, robust.—Wings, above, black, slightly bluish on hairy basal abdominal area of hindwing. _ Forewing with a band extending from base along costal margin to near apex of cell, and then turning backwards in an even curve ending at hinder margin close to angle, costal portion of band red, rest yellow, the band on the whole very little wider in $q$ than in $\delta$; tip of wing yellow. Hindwing not abbreviated in $\delta$, in both sexes with yellow fringe from middle of costal margin close to anal angle, apex and distal margin evenly rounded; $\mathrm{R}^{2}$ very close to $\mathrm{R}^{3}$.

On underside the yellow portion of the band of the forewing wider than above. Length : $\delta$ \&, 27 to $31 \mathrm{~mm}$.

A long series. 
PYRALIDAE.

Vitessidia gen. nov.

§. Palpus very long, curved over the head; second segment the longest, reaching to apex of collar, widened apically, being densely clothed on dorsal side (i.e. nnderside) by somewhat prolonged erect scales, the distal portion of the segment resembling a clothes-brush ; third segment thin, smooth, widening apicad, obliquely truncate, about one-third the length of the second. Eye sparsely hairy. Antenna long, three-fonrths of forewing, ciliated. Tibiae withont tufts, almost smoothly scaled. First segment of tarsi very long, almost twice the length of the others together in foretarsus.

Neuration peculiar : forewing, cross-vein before middle of wing, very deeply incurved, $\mathrm{SC}^{1}$ and $\mathrm{SC}^{2}$ stalked together, from cell close to angle, $\mathrm{SC}^{1}$ branching off at one-third to apex of wing, anastomosing at once with $\mathrm{C}, \mathrm{SC}^{3}$ stalked with $\mathrm{SC}^{4}$ and $\mathrm{SC}^{5}$, the latter being the most distal branch, $\mathrm{R}^{1}$ from the same stalk at one-fourth from cell, $\mathrm{R}^{2}$ and $\mathrm{R}^{3}$ on a long stalk, the pale cross-vein standing close behind $\mathrm{M}^{1}$; hindwing, $\mathrm{R}^{1}$ connected at one-third from cell by a short bar with stalk of $\mathrm{C} . S C^{2}$, the bar representing the proximal portion of the branch $\mathrm{SC}^{2}$, this vein being broadly anastomosed with $\mathrm{C}$; cross-vein angulate, upper one-third situated approximately of middle of wing, oblique lower portion terminating in middle of wing a little beyond $\mathrm{M}^{1}, \mathrm{R}^{2}$ and $\mathrm{R}^{3}$ on a long stalk.

Type: V. diaphana spec. nov.

\section{Vitessidia diaphana spec. nov.}

§. Black, bluish; frons white ; underside (= dorsal) of second segment of palpus grey, some scales on frontal side also grey; pronotum, except a blue-black middle belt, segments 6,7 and 8 of abdomen, breast, coxae and underside of femora yellow-chrome.

Wings, upperside, black, slightly bluish; a large space on forewing from near base to fork $\mathrm{R}^{2} \cdot \mathrm{R}^{3}$, expanding between $\mathrm{C}$ and $\mathrm{SM}^{2}$, a narrow subapical band from $\mathrm{SC}^{4.5}$ to $\mathrm{M}^{1}$, and on hindwing a very large area from near base beyond fork $\mathrm{R}^{2} \cdot \mathrm{R}^{3}$, rounded distally, sinnous, limited by $\mathrm{C}_{\text {and }} \mathrm{SM}^{3}$, transparent but scaled, opalescent in side-view, the veins remaining thinly black; a minute streak of milky white scales at base of forewing before C.

Underside as above, transparent area of hindwing edged with white proximally near base.

Length of forewing: $25 \mathrm{~mm}$.

One $\delta$.

\section{CHALCOSIIDAE.*}

\section{Heteropan alberti spec. nov.}

8. Head and thorax above purplish olive, not glossy; antenna metallic purple above; upperside of abdomen metallic blue, strongly glossy; palpus and forecoxa creamy white, breast, underside of abdomen and legs metallic creamy white, slightly purplish, glossy ; tibiae and tarsi somewhat clayish.

Wings, upperside.—Forewing greenish black, olivaceous, slightly purplish

* Pidorus ericydes Swinhoe, Ann. Mag. N. H. (7). xvi. p. 146. n. 11 (1905) (Woodlark) is the insect which we described as Herpa meeki, the $q$ in Nox. Zool. iii. p. 325 (1897), the $\delta$ ibid. vi. p. 439 (1899). Both sexes are figured ibid. viii, t. 9. fig. 5. 6. (1901). 
in middle, not glossy ; a submarginal band of metallic green spots, extending a short distance basad behind costal margin, stopping posteriorly at $\mathrm{M}^{1} ; \mathrm{SC}^{3}$ stalked with $\mathrm{SC}^{4.5}$ but situated close to cell, $\mathrm{R}^{1}$ from cell.-Hindwing metallic pale blne, strongly glossy, purple in certain lights ; fringe creamy white in upper two-fifths ; $\mathrm{R}^{2}$ and $\mathrm{R}^{3}$ stalked together, $\mathrm{M}^{2}$ from middle of cell.

Underside metallic white from base beyond cell, distal margin metallic pale blue, purplish, this colonr extending along costal margin to one-half; hinder margin of forewing olivaceous, purplish.

Length of forewing : $8 \frac{1}{2} \mathrm{~mm}$.

One $\delta$.

\section{Herpolasia gen. nov.} woolly.

ơ $q$. Frons conical, strongly projecting, rounded. Thorax and base of hindwing

Neuration: Forewing, $\mathrm{SC}^{1}$ anastomosed or connected with $\mathrm{C}, \mathrm{SC}^{2}$ free, $\mathrm{SC}^{3}$ and $\mathrm{SC}^{4}$ on a long stalk, $\mathrm{SC}^{5}$ from this stalk near cell, $\mathrm{R}^{1}$ close to npper angle of cell, veins $\mathrm{R}^{2}$ to $\mathrm{M}^{2}$ from cell._-Hindwing, veins $\mathrm{SC}^{2}$ to $\mathrm{M}^{2}$ from cell.

Type: $I$. augarra spec. nov.

\section{Herpolasia augarra spec. nov.}

§. Body black, purplish; upperside of abdomen metallic bluish green, legs partly greenish blue, a thin occipital belt and the anal tuft orange ; nnderside of abdomen spotted with white; branches of antenna very long.

Wings, upperside.—Forewing black, not glossy, washed with green, and at costal and distal margins and round apex of cell with purple; a donble dot near base, a halfmoon before middle of cell and a subapical dot creamy white, small. Hindwing olive-black, metallic blue from base to three-quarters, a spot on crossveins and a large patch behind cell white.

Underside olive-black.___Forewing with dispersed metallic blne scaling from base to apex of cell, a spot before middle of cell, a larger one on cross-veins and an apical dot creamy white.__ Hindwing : a broad streak from base to middle of cell, with some scattered scales farther distad, and abdominal margin from $\mathrm{SM}^{2}$ backwards, metallic blue; white spots as above, a little larger, the white postcellular patch slightly bordered with blue distally.

+ . Body as in $\delta$, but head and a large spot on mesothoracic tegula white, abdomen withont white spots beneath, glossy blue above; branches of antennal segments abont half as long as in $\delta$.

Wings, upperside.——_Forewing uniformly green-black, with four creamy white spots from base to apex, third the largest, apical one the smallest, all larger than in $\delta$.- Hindwing glossy blue, except the woolly base and the distal and costal marginal borders, the distal border ill defined, gradually narrowing abdominad, the blue colour reaching close to fringe at anal angle.

Underside glossy blue for the greater part; forewing with three white spots, the basal one of upperside being here absent; hindwing with a white dot on cross-veins.

Length : $\delta, 18 \mathrm{~mm}$; + , $22 \mathrm{~mm}$.

One pair.

Chalcosia (?) albomedia Rothschild, Nov. Zool. iv. p. 309. n. 6. t. 7. f. 6 (1897) (Kapaur, Dutch New Guinea), belongs also to this genus, 
42. Doclia cincta spec. nov.

๙. Body black, with a feeble purple gloss, somewhat metallic, legs dirty claycolour beneath.

Wings, upperside.—-Forewing black, with purple reflections, not glossy ; a mesial streak at base and two spots beyond middle yellow, the one spot subcostal, proximally of end of cell, the other behind base of $\mathrm{M}^{1}$; $\mathrm{SC}^{3}$ vestigial, $\mathrm{SC}^{5}$ missing ; $\mathrm{R}^{1}$ stalked with $\mathrm{SC}^{3.4}$ _Hindwing velvety black, a large elongate-ovate yellow area obliquely from costal margin near base toward apex of $\mathrm{M}^{2}$, its hinder edge parallel to abdominal margin.

Underside as upper; forewing less purplish, the basal streak larger, the two postmedian yellow spots merged together to a band; yellow area of hindwing larger, extending close to base of cell.

Length of forewing: $13 \mathrm{~mm}$.

One $\delta$.

43. Doclia (?) melaleuca spec. nov.

ণ. Antennae shortly pectinated proximally, dentate distally. clayish.

Head and pronotum pale yellow; mesonotum white; rest of body black, legs

Wings, upperside.-Forewing truncate as in Heteropan, with three subcostals, $\mathrm{SC}^{3}$ and $\mathrm{SC}^{5}$ being missing, $\mathrm{R}^{1}$ stalked with $\mathrm{SC}^{4}, \mathrm{R}^{2}$ and $\mathrm{R}^{3}$ on a short stalk; chalky white, an olive-black border to distal edge, about $1 \mathrm{~mm}$. wide, extended at apex of wing to cell, the costal portion being $1 \frac{1}{2} \mathrm{~mm}$. broad, abruptly stopping at cell, but extreme costal edge black to base-_-Hindwing smoky black, with slight purple gloss, scaling for the greater part white at base of wing and along abdominal margin, fringe white, except at apex.

Underside olive, with slight purple gloss._-Black border of forewing as above, but less sharply defined._- Costal edge of hindwing, a broad streak in cell, extending to apex of wing, and two streaks between cell and abdominal margin more or less covered with white scales, such scales dispersed over the whole wing ; radial and median veins from cell.

Length of forewing : $12 \mathrm{~mm}$.

One $q$.

\section{Caprima tricolor spec. nov.}

†. Face creamy white; a broad belt behind eyes pale yellow, whitish beneath; rest of body and legs blue, somewhat glossy; antenna luteous at joints, shortly pectinate proximally, dentate distally ; tarsi lutescent.

Wings, upperside.-Forewing: base black, metallic blue; a broad white oblique subbasal band washed with yellow; rest of wing black, with purple reflections; an orange subcostal spot beyond apex of cell.—Hindwing black at base and along abdominal margin from $\mathrm{SM}^{1}$ backwards, more or less metallic blue, apical third of wing also black, slightly purplish, this area widest at apex, narrowing to a point behind, connected with the abdominal streak by some black scattered scales before $\mathrm{SM}^{1}$; rest of wing white.

Underside as above, the metallic and the purple sheen vestigial, the white areas of both wings and the orange spot of forewing somewhat enlarged, 
Neuration: Forewing with three subcostals only, first at four-fifths of cell, second before angle, third at angle close to $\mathrm{R}^{1}, \mathrm{M}^{2}$ a very little more proximal than $\mathrm{SC}^{1}$.

Length of forewing: $10 \mathrm{~mm}$.

One + .

\section{HEPIALIDAE.}

45. Charagia sordida spec. nov.

q. Head, pro- and anterior portions of mesonotum olive-green, rest of thorax and legs greenish olive-buff; abdomen greenish olive ; eye and head small.

Wings, upperside.—Forewing narrower than in the allied species (cyanochlora, marginatus, etc), apex acute, produced, the distal margin being somewhat concave in upper half ; greenish olive-buff, irrorated with the usual olive bars ; a straight shadowy line from four-fifths of costa obliquely across disc, including some silvery spots edged with pink; two brown submarginal spots $\mathrm{SC}^{5}-\mathrm{R}^{2}$; fringe not spotted.Hindwing dirty mummy-brown, with feeble pinkish reflection, slightly greenish at distal and costal edges.

Underside dirty mummy-brown, washed with green costally and distally, and with pink on disc, costal edges marked with greenish olive spots.

Neuration: branches of subcostal fork on forewing a little shorter than, on hindwing as long as, the stem.

Length of forewing: $40 \mathrm{~mm}$.

One ?.

\section{Porina salmonacea spec. nov.}

§. Head and palpus mummy-brown; thorax tawny-olive above and below, slightly pinkish; metanotum and proximal tergites of abdomen salmon-buff, posterior tergites pale cinnamon, sternites olivaceons buff, antenna pale buff, compressed, segments constricted at bases, narrow ventral surface and apical edge of each segment (except end-segment) with fringe of hairs; tibiae and tarsi appearing broad in consequence of long scaling.

Wings, upperside.-Forewing clayish buff or more ochraceons ; behind costa from base to middle three or four creamy white spots, sometimes divided, occasionally partly or all absent or vestigial, encircled with black, the third the largest, in onter half four or five rows of black spots, mostly minute, partly with creamy centres, those of a postdiscal row more or less merged together to a line.-Hindwing salmon-buff at base, pinkish buff distally.

Underside pinkish buff, washed with salmon-colour, costal edge of hindwing yellowish buff.

Length of forewing : 22 to $30 \mathrm{~mm}$.

A series of $\delta \delta$. 


\section{$2 \mathrm{BHL}$ Biodiversity Heritage Library}

Rothschild, Lionel Walter Rothschild and Jordan, Karl. 1905. "On some new Lepidoptera discovered by A. S. Meek in British New Guinea." Novitates zoologicae: a journal of zoology in connection with the Tring Museum 12, 448-478. https://doi.org/10.5962/bhl.part.24275.

View This Item Online: https://www.biodiversitylibrary.org/item/23228

DOI: https://doi.org/10.5962/bhl.part.24275

Permalink: https://www.biodiversitylibrary.org/partpdf/24275

\section{Holding Institution}

Natural History Museum Library, London

\section{Sponsored by}

Natural History Museum Library, London

\section{Copyright \& Reuse}

Copyright Status: Public domain. The BHL considers that this work is no longer under copyright protection.

This document was created from content at the Biodiversity Heritage Library, the world's largest open access digital library for biodiversity literature and archives. Visit BHL at https://www.biodiversitylibrary.org. 